\title{
ISLAM DAN TRADISI LOKAL DI NUSANTARA \\ (Telaah Kritis Terhadap Tradisi Pelet Betteng Pada Masyarakat Madura dalam Perspektif Hukum Islam)
}

\author{
Buhori \\ IAIN Pontianak \\ E-mail: kanghari32@yahoo.co.id
}

\begin{abstract}
Religion and culture are main elements in an interconnected society. When a religion enters a community, there will be a trade-off between the religion and culture e.g. when Islam is descended at Arab which has old tradition. Tradition is part of culture, for that it is not a surprise that every country has tradition including Indonesia. One of Indonesian local tradition is madurese tradition: Pelet Betteng or Pelet Kandhung or Peret Kandung or Salamenddhen Kandhungan which constitutes a pregnancy ritual. It is held by making $d u$ 'a and giving alms in the fourth or seventh month of pregnancy period of a woman who is pregnant for the first time (seriyang). According to sharia perspective, Islam presents without ignoring Arabian tradition ( $a d a h$ ) and convention. They are even considered as sources of Islamic jurisprudence with particular limitations. Therefore, the term of `adat which has a similar meaning to `uruf, has become a basic of istinbath hukm.
\end{abstract}

Keywords: Islam, Local Tradition, Islamic Law.

\begin{abstract}
Abstrak
Agama dan budaya merupakan dua unsur penting dalam masyarakat yang saling mempengaruhi. Ketika ajaran agama masuk dalam sebuah komunitas yang berbudaya, akan terjadi tarik menarik antara kepentingan agama di satu sisi dengan kepentingan budaya di sisi lain. Demikian juga halnya dengan agama Islam yang diturunkan di tengah-tengah masyarakat Arab yang memiliki adatistiadat dan tradisi secara turun-temurun. Tradisi merupakan bagian dari budaya. Salah satu tradisi lokal yang melekat erat dalam kehidupan masyarakat Indonesia, khususnya suku Madura adalah Pelet Betteng,atau terkadang dikenal dengan sebutan Pelet Kandhung atau Peret Kandung atau Salameddhen Kandhungan, yangsecara sederhana diartikan sebagai pijat kandungan atau selamatan kehamilan. Tradisi ini merupakan upacara selamatan yang dilakukan dengan cara pembacaan do`a-do`a dan sedekah, ketika seorang wanita tengah mengandung pertama kalinya (Madura: seriyang) pada saat usia kehamilan mencapai empat bulanatau tujuh bulan.Dalam persepektif hukum Islam, ternyata ajaran Islam sangat memperhatikan tradisi (Arab: `adah) dan konvensi masyarakat untuk dijadikan sumber bagi jurisprudensi hukum Islam dengan penyempurnaan dan batasan-batasan tertentu.Terma `adat yang memiliki kesamaan makna dengan ‘uruf telahmenjadi salah satu landasan dalam istinbat hukum Islam.
\end{abstract}

Kata Kunci: Islam, Tradisi Lokal, Hukum Islam. 


\section{A. Pendahuluan}

Masyarakat Indonesia sangat kaya dengan masalah budaya dan tradisi setempat. Budaya maupun tradisi lokal pada masyarakat Indonesia tidak hanya memberikan warna dalam percaturan kenegaraan, tetapi juga berpengaruh dalam keyakinan dan praktek- praktek keagamaan masyarakat.

Islam, sebagai sebuah agama yang dianut oleh mayoritas masyarakat Indonesia, memiliki hubungan erat dengan kebudayaan atau tradisi-tradisi lokal yang ada di nusantara. Hubungan antara Islam dengan isu-isu lokal adalah kegairahan yang tak pernah usai. Hubungan intim antara keduanya dipicu oleh kegairahan pengikut Islam yang mengimani agamanya: shalihun li kulli zaman wa makan-selalu baik untuk setiap waktu dan tempat. Maka Islam akan senatiasa dihadirkan dan diajak bersentuhan dengan keanekaragaman konteks budaya setempat. Dalam ungkapan lain dapat dikatakan bahwa Islam tidak datang ke sebuah tempat, dan di suatu masa yang hampa budaya. Dalam ranah ini, hubungan antara Islam dengan anasis-anasir lokal mengikuti model keberlangsungan (al-namudzat al-tawashuli), ibarat manusia yang turun-temurun lintas generasi, demikian juga gambaran pertautan yang terjadi antara Islam dengan muatan-muatan lokal di nusantara.

Agama dan budaya merupakan dua unsur penting dalam masyarakat yang saling mempengaruhi. Ketika ajaran agama masuk dalam sebuah komunitas yang berbudaya, akan terjadi tarik menarik antara kepentingan agama di satu sisi dengan kepentingan budaya di sisi lain. Demikian juga halnya dengan agama Islam yang diturunkan di tengah-tengah masyarakat Arab yang memiliki adat-istiadat dan tradisi secara turun-temurun. Mau tidak mau dakwah Islam yang dilakukan Rasulullah harus selalu mempertimbangkan segi-segi budaya masyarakat Arab waktu itu. Bahkan, sebagian ayat al-Qur'an turun melalui tahapan penyesuaian budaya setempat.

Proses adaptasi antara ajaran Islam (wahyu) dengan kondisi masyarakat dapat dilihat dengan banyaknya ayat yang memiliki asbâb al-nuzûl. Asbâb alnuzûl merupakan penjelasan tentang sebab atau kausalitas sebuah ajaran yang diintegrasikan dan ditetapkan berlakunya dalam lingkungan sosial masyarakat. 
Asbâb al-nuzûl juga merupakan bukti adanya negosiasi antara teks al-Qur'an dengan konteks masyarakat sebagai sasaran atau tujuan wahyu.

Islam yang hadir di Indonesia juga tidak bisa dilepaskan dengan budaya dan tradisi yang melekat erat pada masyarakat Indonesia. Sama seperti Islam di kawasan Arab, Arabisme dan Islamisme bergumul sedemikian rupa di kawasan Timur Tengah sehingga kadang-kadang orang sulit membedakan mana yang nilai Islam dan mana yang simbol budaya Arab. Nabi Muhammad saw, tentu saja dengan bimbingan Allah (wama yanthiqu 'anil hawa, in hua illa wahyun yuha ${ }^{1}$ ), dengan cukup cerdik (fathanah) mengetahui sosiologi masyarakat Arab pada saat itu. Sehingga beliau dengan menggunakan tradisi-tradisi Arab untuk mengembangkan Islam. Sebagai salah satu contoh misalnya, ketika Nabi Saw hijrah ke Madinah, masyarakat Madinah di sana menyambut dengan iringan gendang dan tetabuhan sambil menyanyikan thala'al-badru alaina dan seterusnya.

Dalam artikel ini penulis akan mencoba menguraikan sikap akomodatif ajaran Islam terhadap budaya lokal dalam konteks kehidupan keberagamaan pada sebagian besar masyarakat di nusantara ini, dengan salah satu contoh studi kasus pada tradisi Pelet Betteng(peringatan empat bulan dan tujuh bulan kehamilan) yang lazim dilakukan oleh masyarakat Madura, atau pada masyarakat Jawa dikenal dengan sebutan tingkeban yang teridiri dari ngupati dan mitoni.

\section{B. Tradisi Keberagamaan Muslim Indonesia}

\section{Budaya dan Tradisi}

Sebelum memulai pembahasan tentang tradisi Pelet Betteng yang terdiri dari acara pakbulenan dan petongbulenan yang lazim dilaksanakan di kalangan masyarakat Madura di Indonesia,atau masyarakat Jawa mengenalnya dengan istilah Tingkeban (ngupati dan mitoni) sebagai peringatan atau syukuran atas kehamilan seorang istri, penulis terlebih dahulu akan memaparkan mengenai ulasan tentangbudaya dan tradisi.

\footnotetext{
${ }^{1}$ QS. An-Najm (53): 3-4
} 
Secara epistimologi kata budaya berasal dari kata budi dan daya. Budi berarti akal, kecerdikan, kepintaran dan kebijaksanaan, sedangkan Dayamemiliki arti ikhtiar, usaha atau muslihat. Dedi Supriyadi mengartikan bahwa budaya (culture) dapat dipahami sebagai pembangunan yang didasarkan atas kekuatan manusia, baik pembangunan jiwa, pikiran dan semangat melalui latihan dan pengalaman, bukti nyata pembangunan intelektual seperti seni dan pengetahuan. Dengan demikian secara singkat dan sederhana, sebagaimana dipahami secara umum, kebudayaan merupakan semua hasil karya, rasa dan cipta masyarakat ${ }^{2}$.

Karya masyarakat menghasilkan teknologi dan kebudayaan kebendaan (material culture) yang diperlukan manusia untuk menguasai alam sekitarnya. Rasa yang meliputi jiwa manusia, mewujudkan segala kaedah dan nilai-nilai sosial yang perlu untuk mengatur masalah-masalah kemasyarakatan dalam arti luas. Sedangkan cipta merupakan kemampuan mental, kemampuan berpikir orang-orang yang hidup bermasyarakat, antara lain menghasilkan filsafat serta ilmu pengetahuan. ${ }^{3}$

Salah satu bagian dari budaya adalah tradisi. Dalam Kamus Besar Bahasa Indonesia tradisi diartikan sebagai adat kebiasaan turun-temurun(dari nenek moyang) yang masih dijalankan dalam masyarakat; atau juga penilaian atau anggapanbahwa cara-cara yangtelah ada merupakan yang paling baik dan benar ${ }^{4}$. Terminologi tradisi, yang berasal dari katabahasa Inggris tradition, sering juga disamakan dengan lafadz bahasa Arab 'adah. Term ini dipergunakan untuk menunjuk desain atau pola perilakudan kegiatan tertentu menurut standar baku dalam bidangnya masing-masingyang sering dilakukan oleh masyarakat.

Manusia dalam kehidupannya akan senantiasa mengadakan proses

${ }^{2}$ Dedi Supriyadi, Sejarah Peradaban Islam, (Bandung: Pustaka Setia, 2008), 16

${ }^{3}$ Ibid, 18

${ }^{4}$ Departemen Pendidikan Nasional, Kamus Besar Bahasa Indonesia, (Jakarta: Pusat Bahasa, 2008), 1543 
interaksi dan proses sosial lainnya, sehingga tumbuh norma-norma kelompok dan akhirnya melembaga sehinggatampilstruktursosialdalam himpunankelompoktersebut. Norma-norma yang dihasilkan dari hasil karya, cipta dan karsa manusia ini senantiasa dilakukan secara berulang-ulang dan cendrung untuk diwariskan secara turun temurun kepada generasi berikutnya, untuk kemudian menjadi sebuah tradisi yang melekat erat dalam kehidupan mereka. Dalam hal ini, tradisi merupakan sub-sistem dari norma sosial masyarakat yang melahirkan kelompok tersebut.

Namun, perlu juga ditegaskan di sini bahwa agama bukanlah kebudayaan maupun tradisi, karena agama itu diciptakan Tuhan, bukan hasil olah pikir dan karya manusia. Tetapi kelompok-kelompok orang beragama membentuk kebudayaan dan juga tradisi mereka masing-masing sebab mereka mempunyai budi daya dan kebiasaan-kebiasaan yang dilakukan secara terus menerus dalam kehidupannya. Oleh sebab itu, menurut Siradjuddin Abbas (2012: 291) pada hakikatnya tidak ada kebudayaan Islam atau tradisi Islam, namun yang ada adalah kebudayaan dan tradisi orang Islam, karna Islam itu bukan kebudayaan dan tradisi melainkan ciptaan Tuhan Yang Maha Esa. Kebiasaan yang diwariskan secara turun-temurun oleh orang Islam sebagai kelompok masyarakat, dan berlanjut serta dilestarikan hingga saat ini kemudian melembaga di tengah masyarakat itulah yang kemudian dikenal dengan sebutan kebudayaan atau tradisi Islam, yang berarti kebudayaan dan tradisi orang Islam.

Dalam konteks ini pula dapat dipahami mengenai makna terma Islam Nusantara. Pelabelan “Nusantara” terhadap Islam bukan berarti mempersempit syumuliyah ajaran Islam atau mengkotak-kotakkan keluasan ajaran Islam dengan lingkup nusantara, namun ia lebih mengarah pada arti Islam atau keberagamaan orang Islam yang ada di bumi nusantara,yang berarti mengakui bahwa Islam juga terealisasi dalam praktik keseharian. Artinya, selain unsur ilahiyah, Islam juga bersifat insaniyah (manusiawi). Hal ini merupakan pengakuan akan pentingnya pemahaman kontekstual terhadap teks suci dengan mempertimbangkan adat lokal (urf) demi kemaslahatan tak 
hanya dari segi ukhrawi tapi juga duniawi.

\section{Tradisi Keberagamaandi Indonesia}

Terminologi keberagamaan perlu dibedakan dengan term agama atau keagamaan. Di satu sisi, keagamaan berasal dari akar kata agama yang menunjuk pada seperangkat wahyuketuhanan agar menjadi petunjuk kehidupan orang yang beriman untuk mewujudkan kebahagiaan dunia dan akherat. Di sisi lain, term keberagamaan merupakan kata benda dari akar kata beragama. Kata kerja beragama, menunjuk pada produk kegiatan berikut segala aktifitas melaksanakansubstansi ajaran agama oleh orang-orang yang beriman sesuai dengan materi ajaran tersebut ${ }^{5}$.

Dengan demikian,kandunganpengertiankeberagamaan selalu berkaitandengan kekhususan kelompok pemeluk agama, jika dibandingkan dengan himpunan manusia pada umumnya. Dalam posisi ini, himpunan orang beragama atau para pemeluk agama tersebut merupakan unitsosialyangmemilikikesadaran diri bertumpupada jati dirinya sendiri. Maka, pada fenomena ini lahirlah komunitaskeberagamaan yang memiliki karakterisitk atau ciri tertentu.

Agama Islam yang bersumber dari al-Qur_an dan Sunnah dan diyakini sebagai kebenaran tunggal oleh pemeluknya. Akan tetapi, pada saat ajaran yang bersifat transenden ini mulai bersentuhan dengan kehidupan manusia, serta aspek sosio-kultural yang melingkupinya,maka terjadilah berbagai penafsiran yang cendrung berbeda dan berubah-ubah. Hal ini akibat perbedaan kehidupan sosial penganut yang juga terus berubah. Dari perbedaan penafsiran itu lahirlah kemudian pemikiran-pemikiran dalam bidang fiqh dan teologi yang berbeda. Selain itu, realitas ini pula yang pada akhirnya melahirkan tradisi keberagamaan kaum muslimin, yang masingmasing menampakkan cirri khas dari kehidupannya.

Hal tersebut di atas menandakan bahwa meskipun Islam itu satu dari sudut ajaran pokoknya, akan tetapi setelah "terlempar" dalam konteks

5 Muslim A. Kadir, Dasar-Dasar KeberagamaanDalam Islam, (Yoyakarta: PustakaPelajar,2011),56 
sosiokultural-politik tertentu pada tingkat perkembangan sejarah tertentu pula agama bisa memperlihatkan struktur interen yang berbeda-beda. Maka, jika dilihat dari perbedaan persepsi keberagamaan yang biasanya terjadi di kalangan muslimin, maka sejatinya perbedaan itu bukan tentang pokokpokok ajaran Islam itu sendiri, akan tetapi bagaimana memanifestasikan ajaran Islam itu di dalam sistem kehidupan sosial, antara Islam sebagai model of reality dan Islam sebagai models for reality, sehingga menciptakan setidaknya dua bentuk komunitas beragama yaitu antara folk variant dan scholarly veriant, yang dalam konteks keindonesiaan terwujud dalam bentuk komunitas atau kelompok tradisionalis, dan kelompok modernis ${ }^{6}$.

Kelompok tradisionalis sering dikategorikan sebagai kelompok Islam yang masih mempraktekkan beberapa praktek tahayyul, bid'ah, khurafat, dan beberapa budaya animisme, atau sering diidentikkan dengan ekspresi Islam lokal, sementara kelompok modernis adalah mereka yang sudah tidak lagi mempraktekkan beberapa hal di atas. Akan tetapi kategorisasi dan polarisasi ini menjadi kurang tepat ketika ditemukan adanya praktek budaya animisme yang dilakukan oleh kalangan muslim modernis. Selain itu, klaim Islam tradisional sebagai pelaku tahayul, bid`ah dan khurafat dewasa ini kurang menemukan pijakannya. Sebab kalangan muslim tradisional bukanlah pelaku perbuatan itu, karna memang dalam ajaran Islam perbuatan-perbuatan yang menjurus kepada Tahayyul, bid`ah dan khurafat sangat dilarang. Melainkan Islam tradisionalis lebih menekankan kepada kesadaran untuk menghargai tradisi dan budaya yang sudah ada di tengah masyarakat.

Tradisi keberagamaan yang berkembang di kalangan Islam tradisionalis tampak lebeih toleran terhadap nilai-nilai tradisi dan budaya lokal setempat. Kalangan ini meyakini, ajaran Islam datang dan tersebar ke penjuru dunia, bukan untuk mengganti budaya dan tradisi yang ada dengan tradisi dan budaya Arab sebagai tempat awal diutusnya nabi Muhammad saw sang pembawa risalah Islam. Ajaran Islam juga tidak mengharamkan

${ }^{6}$ Taufik Abdullah, Islam dan Masyarakat, (Jakarta: LP3S, 1996), 11. 
orang-orang Islam untuk berbudaya dan beradat istiadat sesuai dengan kulturnya, karna budaya merupakan bagian dari kehidupan manusia yang tidak dapat dipisahkan, selama ia hidup di dunia ini. Selama tradisi dan budaya itu tidak bertentangan dengan syari`at Islam yang telah ditetapkan, maka menurutnya sah-sah saja untuk tetap dilaksanakan dan dilestarikan.

\section{Prosesi Pelet Betteng, Adat Kehamilan Masyarakat Madura}

Salah satu tradisi lokal yang melekat erat dalam kehidupan masyarakat Indonesia adalah Pelet Betteng, atau dalam bahasa Jawa dikenal dengan sebutanTingkebanyang mengandung makna "seng dienti-enti wis mathuk jangkep” (yang dinanti-nanti sudah hampir sempurna). Selain itu, juga dikenal beberapa istilah lain sepertiNgupati dan Mitoni. Pelet Betteng, ngupati dan mitoni merupakan tradisi atau upacara selamatan yang dilakukan dengan cara pembacaan do`a-do`a dan sedekah, ketika seorang wanita tengah mengandung pada usia kandungan 4 bulan (ngupati) atau tujuh bulan (mitoni). Dalam upacara inibiasanya dibacakan surah Yusuf, Maryam dan Muhammad, dengan maksud tabarrukan (mengambil berkah) dari kisah-kisah Nabi yang dikisahkan dalam surat-surat tersebut ${ }^{7}$.

Tradisi Tingkeban (Bahasa Madura: Pelet Betteng) ini berkembang luas di tengah masyarakat dan lazim dilakukan, khususnya oleh masyarakat Jawa dan Madura yang notabenenya mayoritas kaum Nahdliyin. Upacara ini dilakukan dengan harapan agar bayi yang berada dalam kandungan diberikan keselamatan, lahir dengan selamat dan menjadi anak yang saleh dan ditakdirkan dalam kebaikan kelak ketika lahir ke dunia.

IstilahPelet Bettengsendiri berasal dari bahasa Madura yang secara harfiah mempunyai arti pijat kandungan. Di kalangan masyarakat Maduratradisi ini juga sering dikenal dengan sebutan Pelet Kandhung atau Peret Kandung atau Salameddhen Kandhungan.Sebenarnya upacara pelet betteng ini mirip dengan tradisi yang biasa dilaksanakan oleh beberapa

${ }^{7}$ Soleiman Fadeli \& M.Subhan, Antologi Sejarah Istilah Amaliah Uswah NU, (Buku I, Surabaya: Khalista, 2012), 158 
tempat di nusantara ketika masa kehamilan telah mencapai usia 7 bulan. Tapi seperti halnya pepatah lama yang berbunyi lain lubuk lain belalang, maka meskipun upacara ini sama-sama dilakukan oleh orang yang sedang hamil, tapi tentu saja cara dan prosesi yang dilakukan berbeda-beda.

Upacara Pelet Betteng ini lazim dilakukan hanya pada saat hamil pertama seorang Istri.Sedangkan untuk kehamilan berikutnya, biasanyaupacara yang dilaksanakan tidak semeriah pada kehamilan pertama, namun tetap dilaksanakan dengan sederhana, yaitu yang umumnya berupasalameddhan (selamatan) dengan cara mengundang beberapa tokoh agama (ustadz) dan masyarakat sekitar untuk membaca ayat-ayat Al-Qur`an dan do`a untuk keselamatan calon bayi serta ibunya serta mendo`akan agar anak yang dilahirkan kelak menjadi anak yang solih/solihah. Cara lainnya terkadang dilakukan dalam bentuk arebbha (hantaran nasi kepada kiyai, tokoh agama atau kerabat terdekat untuk diminintakan do`anya atas keselamatan janin dalam rahim).Upacara ini dilakukan pada saat kandungan berusia tujuh bulan (Madura: petong bulen), dan biasanya diawali dengan upacara selamatan pada usia kandungan empat bulan (Madura; pak bulen). Pada masa itu merupakan masa pembentukan janin yang wajib dirawat dan diruwat. Perawatan dilakukan dengan menjaga calon ibu agar kondisinya tetap sehat, terjaga dan janin yang dikandungnya juga sehat. Sedangkan meruwat nya dilakukan dengan cara mendo`akan janin yang dikandungnya serta calon ibu agar diberi keselamatan dan diberikan kemudahan dalam proses persalinan.

Secara tradisional masyarakat Madura cenderung tahap demi tahap melakukan Pelet Betteng sebagai bentuk pencegahandan penghindaran agar bayi yang dikandungnya tidak mengalami masalah sehingga ketika bayi dilahirkan berjalan lancar dan aman. Oleh karena masa-masa tersebut dianggap sebagai masa yang penuh dengan ancaman dan bahaya, maka diperlukan adanya suatu usaha untuk menetralkannya, sehingga dapat dilalui dengan selamat. Usaha tersebut diwujudkan dalam bentuk upacara yang kemudian dikenal sebagai upacara lingkaran hidup individu yang meliputi: 
kehamilan, kelahiran, khitanan, perkawinan, dan kematian.

Upacara adat ini biasanya dilakukan dari pihak keluarga perempuan atau orang tua dari anak yang hamil. Ada pula dilaksanakan oleh pihak mertua, orang tua suami. Hal ini tergantung kesepakatan, dan umumnya untuk wilayah Madura Timur, pihak keluarga laki-laki meminta agar dilaksanakan di rumah si suami mengingat berbagai pertimbangan.Upacara ini diawali dengan pembacaan ayat-ayat Al-Quran (Surat Yusuf, Maryam, dan beberapa surat lainnya dalam Al-Qur`an) oleh para undangan laki-laki yang dipimpin oleh seorang Kyaeh/kiyai atau bhindereh/ ustadz. Pada prosesi ini akan diakhiri dengan acara makan bersama sajian yang telah disediakan oleh tuan rumah. Sajian khas yang lazim diberikan oleh tuan rumah adalah rujak yang terbuat dari buah nanas, mentimun dan kacang tanah.

Selagi para lelaki itu membaca Al-quran dan do`a di ruang tamu, di dalam bilik perempuan yang mengandung itu mulai dilaksanakan prosesi pelet kandhung atau memijit/mengurut si calon ibu. Dalam proses ini dukon beji' (dukun bayi) berperan penting, yang nantinya akan memimpin proses upacara adat. Dukon beji mulai memelet atau memijat bagian perut perempuan tersebut dengan menggunakan minyak kelapa. Maksud dari tindakan ini adalah untuk mengatur posisi bayi di dalam kandungan. Pada saat Dukon beji` itu memijit perut perempuan hamil itu, secara bergiliran sanak kerabat akan masuk kedalam bilik untuk mengusap perut si perempuan hamil itu sembari memanjatkan do`a agar si calon ibu dan bayinya selalu dilindungi Tuhan sampai proses melahirkan kelak.

Prosesi berikutnya dilanjutkan dengan penyepakan ayam. Sang dukon beji akan membimbing si ibu hamil menuju ayam yang diikat di kaki ranjang untuk di sepak sampai menimbulkan bunyi "keok". Ayam yang telah disepak ini nantinya setelah upacara selesai akan diberikan kepada dukun bayi sebagai ucapan terima kasih sekaligus sebagai pengurip. Setelah tahap penyepakan ayam dilewati maka sang dukun bayipun kembali membimbing si ibu hamil tadi menuju prosesi berikutnya yakni upacara 
penginjakan telur dan kelapa muda. Dalam prosesi ini si ibu hamil terlebih dahulu diminta untuk memakai kain putih untuk kemudian disuruh kaki kanannya menginjak kelapa muda, dan kaki kiri menginjak telur. Yang unik dari prosesi ini adalah apabila telur yang diinjak itu berhasil dipecahkan maka mereka meyakini bahwa anak yang bakal lahir nanti berjenis kelamin laki-laki. Tapi bila tak berhasil dipecahkan maka si dukun bayi akan memungut telur tersebut untuk digelindingkan ke perut sang ibu hingga menggelinding menyentuh tanah. Begitu telur itu pecah maka para undangan yang hadir pun akan berseru “Jebbing! Jebbing!” yang berarti bahwa bayi yang akan lahir kelak berjenis kelamin perempuan.

\section{Tahap ritual dimandikan}

Pada tahap ini ibu hamil dimandikan oleh kerabat menggunakan air tertentu yang telah diberi kembang setaman di kamar mandi atau halaman belakang. Sang dukun baji ini pertama-tama akan mengambil gayung terbuat dari tempurung kelapa dan gagangnya dari ranting pohon beringin yang masih ada daunnya, kemudian menaburkan kembang setaman dan uang logam ke dalam air kongkoman dari periuk tanah, kemudian mengambil air tersebut menggunakan gayung tadi lalu diguyurkan kepada si ibu hamil. Selesai dukun baji barulah kemudian giliran kerabat dan handai taulan si ibu hamil ikut memandikan menggunakan air yang sama tadi hingga air kongkoman habis. Selesai dimandikan kemudian si ibu hamil ini pun akan dibawa kembali ke dalam kamar untuk dirias dan dipakaikan baju paling bagus agar begitu si ibu hamil di bawa keluar menemui tamu undangan para tamu akan berseru “Radin! Radin!” yang berarti cantik.

Setelah itu, acara diteruskan dengan penyerahan dua buah cengker yang telah digambari tokoh wayang Arjuna dan Sembodro kepada Kyae untuk didoakan. Setelah selesai didoakan barulah cengker itu kembali diserahkan kepada matowa bine untuk diletakkan di tempat tidur menantu perempuannya yang sedang hamil itu hingga si perempuan melahirkan bayinya. 
Tahap terakhir adalah pemberian jamu dek cacing towa untuk diminum si ibu hamil dan pemberian nasi ponar dan telur rebus. Oh iya, setelah jamu dek cacing towa diminumkan maka tempat jamu (cengkelongan) itu kemudian dilemparkan ke halaman. Masyarakat Madura meyakini bahwa jika cengkolan tersebut jatuh terlentang maka bayi yang akan lahir akan berjenis kelamin laki-laki dan sebaliknya.

\section{Tahap Orasol atau kenduri}

Pada tahap ini semua tamu undangan akan diajak makan bersama dengan hidangan-hidangan khas upacara pelet kandhung seperti Kue procut, juadah pasar (jajanan pasar), lemeng (ketan yang dibakar dalam bambu), tettel (penganan yang terbuat dari ketan), minuman cendol, la’ang dan bunga siwalan (semacam legen) dan sebagainya sebagai ungkapan syukur kepada Tuhan sekaligus terimakasih kepada semua kerabat yang telah ikut membantu terlaksananya upacara pelet kandhung ini ${ }^{8}$.

\section{PeletBeteeng dalam Perspektif Hukum Islam}

Islam sangat memperhatikan tradisi dan konvensi masyarakat untuk dijadikan sumber bagi jurisprudensi hukum Islam dengan penyempurnaan dan batasan-batasan tertentu. Prinsip demikian terus dijalankan oleh Nabi Muhammad SAW. Kebijakan-kebijakan beliau yang berkaitan dengan hukum yang tertuang dalam sunnahnya banyak mencerminkan kearifan beliau terhadap tradisi-tradisi para sahabat atau masyarakat.

Dalam hadits yang diriwayatkan oleh Ahmad dari Abdullah ibn Mas'ud ${ }^{9}$ disebutkan,

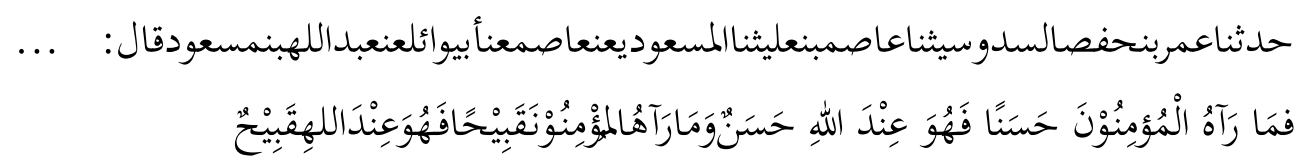

Artinya: "Dicertikana kepada kami `Amr bin Hafs as-Sudusi, menceritakan `Ashim in Ali, menceritakan al-Mas `udy, dari `Ashim dari Abi Wail

\footnotetext{
${ }^{8}$ http://arsipbudayanusantara.blogspot.co.id/2014/11/ upacara-peletkandhung-pada-masyarakat.html, (diakses pada tanggal 14 Juli 2017)

${ }^{9}$ Sulaiman bin Ahmad bin Ayyub Abul Qosim Al-Tobroni, Al-Mu `jam al-Kabir, Juz 9 (Maktabah Syamilah, Isdor Tsnai), 112
} 
dari Abdilah bin Mas`ud ia berkata: ... Apa yang dipandang baik oleh orang-orang mukmin, maka ia di sisi Allah pun baik, dan apa saja yang dipandang buruk oleh orang-orang mukmin, maka buruk pula ia di sisi Allah"

Hadis tersebut oleh kalangan ushuliyyindipahami (dijadikan dasar) bahwa tradisi masyarakat yang tidak bertentangan dengan prinsip-prinsip syari'at Islam dapat dijadikan dasar pertimbangan dalam menetapkan hukum Islam (fiqh). Berdasarkan hadits itu pula kemudian dirumuskan suatu kaedah dalam ushul fiqh yang juga mendukung masuknya budaya dan tradisi dalam

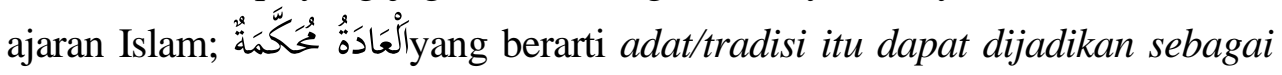
hukum”. Adat dalam kaedah fiqih di atas secara bahasa berarti mu awadatus syai i wa tikroruhu(membiasakan sesuatu dan mengulang-ulangnya). Dalam hal ini terma adat memiliki kesamaan makna dengan `uruf. Oleh sebab itu, dari sisi terminologi adat tersebut didefinisikan sebagai sesuatu yang telah masyhur di kalangan masyarakat dan telah dikenal secara luas, serta tidak bertentangan dengan syari`at Islam ${ }^{10}$. Keidentikan adat dengan `uruf sebagai salah satu landasan dalam istinbat hukum Islam, menjadikan alasan kalangan ushuliyyin untuk mendasarkan kaedah fiqih di atas dengan salah satu ayat AlQur`an berikut:

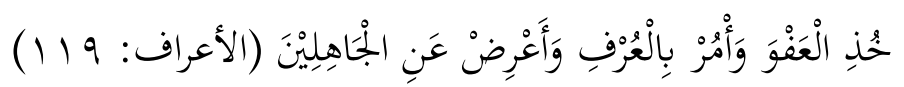

Artinya: jadilah Engkau Pema'af dan suruhlah orang mengerjakan dengan 'urf, serta berpalinglah dari pada orang-orang yang bodoh ${ }^{11}$.

Terkait dengan tradisi mendo akan anak sejak dalam kandungan, banyak sekali ayat-ayat Al-qur`an yang menganjurkannya. Dianatara pada QS. Al-A raf: 189:

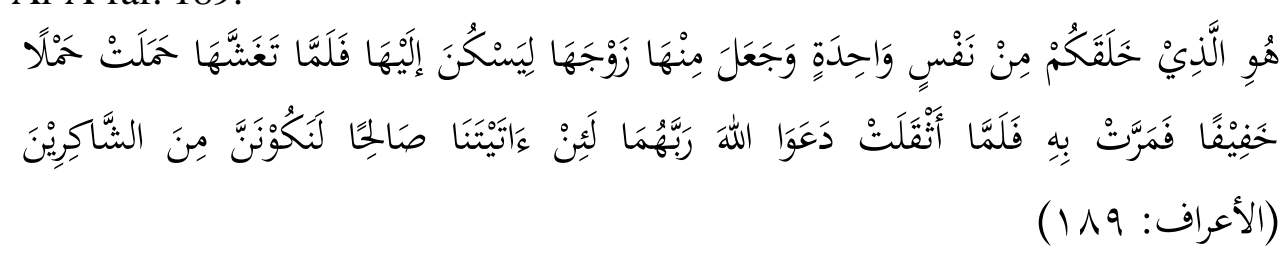

"Dialah yang menciptakan kamu dari diri yang satu dan dari padanya Dia menciptakan isterinya, agar Dia merasa senang kepadanya. Maka setelah dicampurinya, isterinya itu mengandung kandungan yang ringan, dan teruslah Dia merasa ringan (Beberapa waktu). kemudian tatkala Dia merasa berat, keduanya (suami-isteri) bermohon kepada Allah, Tuhannya seraya berkata: "Sesungguhnya jika Engkau memberi Kami anak yang saleh, tentulah Kami terraasuk orang-orang yang bersyukur". (al-A`raf: 189)

10 Riyadh bin Mansur al-Akholifi, al-Mihhaj fi `ilmil Qowa`id alFiqhiyyah, Juz 1 (Maktabah Syamilah, Isdor Tsnai), 10

${ }^{11}$ QS. al-A`raf (07): 119 
Nabi Ibrahim as. juga senantiasa mendo`akan anak cucunya. Sebagaimana yang terekam dalam QS. Al-Baqarah: 128:

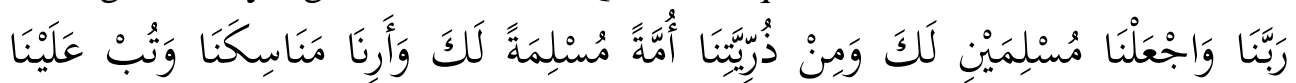

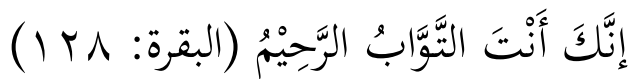

"Ya Tuhan Kami, Jadikanlah Kami berdua orang yang tunduk patuh kepada Engkau dan (jadikanlah) diantara anak cucu Kami umat yang tunduk patuh kepada Engkau dan tunjukkanlah kepada Kami cara-cara dan tempat-tempat ibadat haji Kami, dan terimalah taubat kami. Sesungguhnya Engkaulah yang Maha Penerima taubat lagi Maha Penyayang.(Al-Baqarah: 128)

Dalam kitab al-Qur`an juga banyak sekali ayat-ayat yang berisi anjuran kepada umat Islam untuk senantiasa mendo`akan anak cucunya agar menjadi orang yang baik dan bertaqwa. Seperti yang tertera pada QS. Al-Furqon: 74:

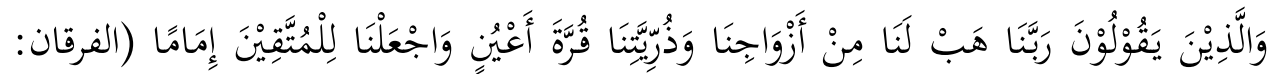

"dan orang orang yang berkata: "Ya Tuhan Kami, anugrahkanlah kepada Kami isteri-isteri Kami dan keturunan Kami sebagai penyenang hati (Kami), dan Jadikanlah Kami imam bagi orang-orang yang bertakwa.(alFurqon: 74)

Dalam Kitab Dalail an-Nubuwah ${ }^{12}$, Al-Imam al-Hafizh al-Baihaqi meriwayatkan bahwa Rasulullah saw. mendoakan janin Ummu Sulaim, istri Abu Thalhah agar berkah.

$$
\begin{aligned}
& \text { عن أنس بن مالك، قال: كان لأم سليم من أبي طلحة ابن فمرض مرضه الذي مات فيه، فلما } \\
& \text { مات غطته أمه بثوب فدخل أبو طلحة فقال: كيف أمس ابني؟ قالت: أمس هادئا، فتعشى ثم } \\
& \text { قالت له في بعض الليل: أرأيت لو أن رجلا أعارك عارية ثم أخذها منك إذاً جزعت ؟ فقال: } \\
& \text { لا، فقالت: فإن الله أعارك ابنك، وقد أخذه منك، قال: فغدا إلى رسول الله صلى الله عليه } \\
& \text { وسلم، فأخبره بقولها، وقد كان أصاها تلك الليلة، فقال النبي صلى الله عليه وسلم: بارك الله } \\
& \text { لكما في ليلتكما، قال: فولدت له غلاما كان اسمه عبد الله، قال: فذكروا أنه كان من خير أهل }
\end{aligned}
$$

${ }^{12}$ Ahmad bin Husain bin Ali bin Musa al-Baihaqi, Dalail an-Nubuwwah wa Ma `rifatu Ahwalis Sohibis Syari`ah, Juz 6, (Beirut: Darul Kutub al-`Ilmiyyah, 1988),198 
Dari Anas bin Malik, ia berkata: Ummu Sulaim Sitri Abu Talhah memiliki anak laki-laki yang sedang sakit, dimana sakinya itu menghantarkan ia pada kematiannya. Setelah anaknya mati, maka Ummu Sulaim menutupinya dengan baju. Kemudian Abu Talhah masuk dan bertanya: Bagaimana keadaan anakku ? Ummu Sulaim menjawab; dia dalam keadaan tenang. Pada saat makan malam, Ummu Sulaim berkata kepada Abu Talhah: bagaimana menurutmu, jika ada seseorang yang menitipkan sesuatu kepadamu kemudian orang itu mengambilnya, apakah engkau akan bersedih atau berkeluh kesah ? Abu Talhah menjawab: tidak, Ummu Sulaim berkata: Allah swt. telah menitipkan seorang anak laki-laki kepadamu, dan sekarang Dia telah mengambilnya darimu. Kemudian, pada pagi harinya Abu Talhah datang menemui Rasulullah dan menceritakan hal ihwal yang dikatakan Ummu Sulaim dan apa yang ia alami pada malam tersebut, maka nabi bersabda: Semoga Allah swt. memberkahi kalian berdua pada waktu malam kalian. Abu Talhah berkata: kemudian Ummu Sulaim melahirkan seorang anak yang bernama Abdullah, yang menurut riwayat ia termasuk salah satu orang terbaik pada masanya.(HR. Baihaqi)

Selain ayat-ayat al-Qur`an dan hadits di atas, anjuran untuk senantiasa mendoakan anak sejak dalam kandungan juga banyak dicontohkan oleh para ulama. Di antaranya yang telah dilakukan oleh Imam Ahmad bin Hanbal yang terbiasa mendoakan dan membagi-bagikan hadiah ketika istri beliau sedang hamil. Al-Imam Ibn al-Jauzi meriwayatkan dalam kitabnya Manaqib al-Imam Ahmad bin Hanbal, (406-407), bahwa keluarga al-Imam Ahmadi bin Hanbal, membagi-bagikan sedekah ketika istri beliau (al-Imam Ahmad bin Hanbal) hamil.

Berkenaan dengan tradisi jamuan dan beberapa rangkaian ritual yang terdapat pada tradisi Pelet Betteng, dalam pandangan fiqih, segala bentuk jamuan yang disuguhkan dan dihidangkan dalam waktu-waktu tertentu, seperti saat pesta pernikahan, khitanan dan kelahiran atau hal-hal lain yang ditujukan sebagai wujud rasa kegembiraan disebut walimah. Menurut madzhab Syafi i mengadakan perjamuan/hidangan selain untuk walimatul urusy hukumnya sunat, sebab hidangan tersebut dimaksudkan untuk menampakkan rasa syukur atas kenikmatan dari Allah swt. dan dianjurkan juga untuk menghadiri undangan jamuan tersebut dengan tujuan menyambung hubungan baik antar sesama umat Islam. Nabi Muhammad saw bersabda: 


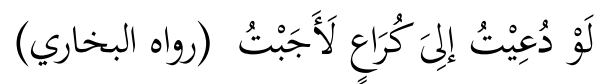

Seandainya aku diundang untuk perjamuan makan sebesar satu paha belakang (kambing), pasti akan aku penuhi (Sohih Bukhori, no. 5178)

Dilihat dari rangkaian ritual yang dilakukan pada tradisi Tingkeban, dapat dikatakan bahwa tradisi Tingkeban, baik berupa ngupati (Jawa), pak bulenan(Madura), atau mitoni (Jawa) / pitong bulenan(Madura) merupakan tradisi yang dilakukan dengan cara-cara yang tidak bertentangan dengan syari at Islam, oleh karna tradisi ini diisi dengan pembacaan do`a terhadap janin dalam kandungan dan pemberian sedekah berupa hidangan, yang mana hal tersebut sangat dianjurkan dalam Islam. Oleh sebab itu, tradisi ini hukumnya boleh dilakukan karna termasuk dalam kategori walimah yang bertujuan untuk menampakkan rasa syukur akan kenikmatan dari Allah swt. berupa akan lahirnya seorang bayi.Terlebih lagi apabila hidangan tersebut disuguhkan dengan mengundang orang lain dan diniati untuk sedekah serta sebagai permohonan agar ibu yang mengandung dan anak yang dikandungnya diberi keselamatan oleh Allah swt. Para ulama sepakat bahwa memberi sedekah adalah sunat, apalagi dilakukan pada saat-saat penting seperti bulan Ramadhan, saat terjadi gerhana, saat sakit dan lain-lain. Dalam sebuah hadis diriwayatkan:

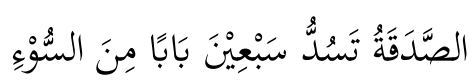

“Bersedekah itudapat menutup tujuh puluh macam keburukan” (Mu’jam Kabir li at-Thobroni. No. 4402)

Landasan normatif-theologis atas tradisi pellet betteng dalam persepktif hukum Islam juga dapat ditelusuri keberadaannya dalam kaedah Fiqhiyyah. Sebagaimana disebutkan dalam kaedah fiqhiyyah ke dua belas:

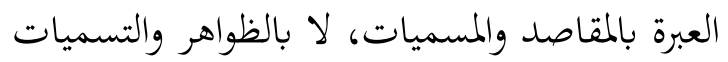

"yang dijadikan tolok ukur dalam sebuah perkara adalah tujuan (maqashid) dan subtansinya, bukan fenomena luar dan penamaannya” 
Dalam konteks tradisi pellet betteng, kendatipun tidak ada satu riwayatpun yang menjelaskan tentang pernah dilakukannya ritual ini pada masa nabi atau sahabat, namun melihat aspek maqashid dan subtansi yang terdapat di dalamnya maka tradisi ini secara gamblang dapat dikatakan sebagai tradisi yang tidak menyalahi syari`at Islam, memiliki tujuan yang baik, serta subtansi yang terdapat di dalamnya merepresentasikan nilai-nilai ajaran Islam. Oleh karnanya, tidak ada larangan yang bersifat syar i atas keberadaan tradisi semacam ini.

\section{Kesimpulan}

Sebagai catatan penutup perlu ditegaskan bahwa Islam tidak sama sekali menolak tradisi atau budaya yang berkembang ditengah-tengah masyarakat. Dalam penetapan hukum Islam dikenal salah satu cara melakukan ijtihad yang disebut'urf, yakni penetapan hukum dengan mendasarkan pada tradisi yang berkembang dalam masyarakat. Dengan cara ini berarti tradisi dapat dijadikan dasar penetapan hukum Islam dengan syarat tidak bertentangan dengan ajaran Islam yang tertuang dalam al-Quran dan hadis Nabi Saw. Di Indonesia banyak berkembang tradisi dikalangan umat Islam yang terus berlaku hingga sekarang, seperti tradisi lamaran, tingkeban, sumbangan mantenan, peringatanhari-hari besar keagamaan, dan lain sebagainya. Selama ini tidak bertentangan dengan ajaran Islam maka tradisi-tradisi seperti itu dapat dilakukan dan dikembangkan. Sebaliknya, jika bertentangan dengan ajaran Islam, maka tradisi-tradisi itu harus ditinggalkan dan tidak boleh di kembangkan.

Islam sangat memperhatikan sekali masalah adat istiadat suatu masyarakat, karena ia dapat mempengaruhi pembentukan hukum. Para imam mazhab saja, banyak sekali memperhatikan kepada adat istiadat setempat. Fatwa-fatwa Imam Abu Hanifah misalnya, berbeda dengan fatwa-fatwa dari murid-muridnya lantaran perbedaan kebiasaan mereka masing-masing; Imam Syafi i setelah pindah ke negeri Mesir mengganti fatwanya sesuai dengan adat kebiasaan yang berlaku dan dipraktekkannya di negara baru, hingga fatwa-fatwa beliau itu dapat dibedakan sewaktu masih berada di Bagdad dengan fatwa beliau sesudah pindah ke Mesir. 
Setiap perbuatan yang diterima oleh mayoritas ummat Islam, dikategorikan sebagai perbuatan yang baik di sisi Allah SWT, sebab tidak mungkin orang banyak bersepakat dalam masalah kejelekan. Setiap adat kebiasaan yang berlaku pada suatu masyarakat serta tidak melanggar ketentuan syariat, harus tetap dipelihara dan diamalkan. Sebaliknya, adat kebiasaan yang menyimpang dari ketentuan syariat, walaupun banyak dikerjakan orang, tetap tidak boleh diamalkan, lantaran di dalam hadist di atas diberi predikat hasanan (baik), yang sudah barang tentu menurut ukuran syari at dan logika.

\section{Daftar Pustaka}

Al-Qur`an dan Terjemahan.

Abu Bakar Ahmad Bin Husin al-Baihaqi, Dalail an-Nubuwah wa Ma`rifati Ahwal Sohibi as-Syari `ah, (Bairut: Darul Kutub al-`Ilmiyyah, TT).

Dedi Supriyadi, Sejarah Peradaban Islam, (Bandung: Pustaka Setia, 2008).

Departemen Pendidikan Nasional, Kamus Besar Bahasa Indonesia, (Jakarta: Pusat Bahasa, 2008)

Muslim A. Kadir, Dasar-Dasar KeberagamaanDalam Islam, (Yoyakarta: PustakaPelajar,2011).

Riyadh bin Mansur al-Akholifi, al-Mihhaj fi `ilmil Qowa`id al-Fiqhiyyah, Juz 1 (Maktabah Syamilah, Isdor Tsnai).

Siradjuddin Abbas, 40 Masalah Agama 3, (Jakarta: Pustaka Tarbiyah Baru, 2012).

Soleiman Fadeli \& M.Subhan, Antologi Sejarah Istilah Amaliah Uswah NU, Buku I, (Surabaya: Khalista, 2010)

Sulaiman bin Ahmad bin Ayyub Abul Qosim Al-Tobroni, Al-Mu jam al-Kabir, Juz 9 (Maktabah Syamilah, Isdor Tsnai).

Taufik Abdullah, Islam dan Masyarakat, (Jakarta: LP3S, 1996).

http://arsip budaya nusantara.blogspot.co.id/2014/11/ upacara pelet kandhung pada masyarakat.html. 